Revista Brasil. Bot., V.32, n.3, p.521-530, jul.-set. 2009

\title{
Habitat utilization and CAM occurrence among epiphytic bromeliads in a dry forest from southeastern Brazil ${ }^{1}$
}

\author{
TALITA FONTOURA ${ }^{2,4}$ and FERNANDA REINERT ${ }^{3}$
}

(received: January 17, 2008; accepted: May 13, 2009)

\begin{abstract}
Habitat utilization and CAM occurrence among epiphytic bromeliads in a dry forest from southeastern Brazil). We studied the community and habitat occupation of epiphytes to understand how these plants cope with a supposedly stressful habitat: i) how general epiphytes occupy tree trunks, ii) how epiphytic bromeliads, occupy their supportive trees, iii) how CAM bromeliads are spatially distributed. The study was done in the dry forest of Jacarepiá, State of Rio de Janeiro. Data collection on epiphytes, phorophytes, and trees was based on the point-center quarter method. The photosynthetic pathway of the bromeliad species was determined using isotope ratio mass spectrometry. The presence of Gesneriaceae, Araceae, and Cactaceae indicates that some humidity is present in the area allowing the presence of supposedly less-specialized epiphytes. There was no correlation between epiphyte abundance and phorophyte diameter, and phorophytes had larger sizes than trees that do not host epiphytes. There was correlation between tree diameter and bromeliad abundance, and lack of correlation between diameter and bromeliad richness. Only one species was typical of the understorey and one was typical of the canopy, while intermediate heights were occupied by different species. The only $\mathrm{C}_{3}$ bromeliad species (Vriesea procera (Mart. ex Schult.f.) Wittm.) was significantly more exposed than the other species. If CAM occurrence is related to water economy, the fact that a $\mathrm{C}_{3}$ species is subjected to more exposed conditions is remarkable. Further comments are presented on the proportion between CAM bromeliad species and abundance in dry forest. Regarding life forms, holoepiphytes, as opposed to hemiepiphytes, showed not to be restricted by the phorophyte's diameter suggesting a more successful establishment of this life form.
\end{abstract}

Key words - Atlantic rainforest, Bromeliaceae, canopy, restinga vegetation

RESUMO - (Utilização de hábitat e ocorrência do metabolismo CAM entre bromélias epífitas em uma floresta seca do sudeste do Brasil). Investigamos a comunidade e a ocupação de epífitas da floresta seca de Jacarepiá, Rio de Janeiro para entender: i) como epífitas em geral ocupam troncos das árvores; ii) como bromélias epífitas ocupam árvores suporte; iii) distribuição espacial de bromélias CAM. A coleta de dados sobre epífitas, forófitos e árvores foi baseada no método ponto quadrante central. A via fotossintética das bromélias epífitas foi determinada por espectrometria de massa. A presença de Gesneriaceae, Araceae e Cactaceae indicam umidade suficiente para permitir a presença de epífitas supostamente menos especializadas. Não houve correlação entre abundância de epífitas e diâmetro dos forófitos, e forófitos possuíram maior tamanho que árvores sem epífitas. Houve correlação entre diâmetro das árvores e abundância de bromélias e falta de correlação entre diâmetro e riqueza de bromélias. Somente uma espécie foi típica da submata e outra do dossel. Estes resultados diferem do padrão de ocupação de microsítios por epífitas, sugerindo que as copas das árvores são locais super-expostos para bromélias. A única espécie $\mathrm{C}_{3}$ (Vriesea procera (Mart. ex Schult. f.) Wittm.) estava significativamente mais exposta que as demais espécies no dossel. Se a ocorrência de CAM é relacionada à economia de água, o fato desta espécie estar sujeita a condições de maior exposição é notável. Comentários adicionais são apresentados sobre a proporção entre espécies de bromélia CAM e abundância. Em relação às formas de vida, holoepífitas ocorreram em todos os diâmetros dos forófitos ao contrário das hemiepífitas, sugerindo que holoepíftas possuem um estabelecimento melhor sucedido que hemiepífitas.

Palavras-chave - Bromeliaceae, dossel, Floresta Atlântica, restinga

\section{Introduction}

Low rainfall is one of the limiting factors for the presence of epiphytes. In forested areas with low rainfall,

1. Part of the M.Sc. dissertation of the first author, Programa de Pós Graduação em Ecologia, Universidade Federal do Rio de Janeiro, Rio de Janeiro, Brazil.

2. Universidade Estadual de Santa Cruz, Departamento de Ciências Biológicas, Rod. Ilhéus-Itabuna, km16, 45650-000 Ilhéus, BA, Brazil.

3. Universidade Federal do Rio de Janeiro, CCS, Departamento de Botânica, IB, 21941-970 Rio de Janeiro, RJ, Brazil.

4._Corresponding author: talita_fontoura@uol.com.br epiphytes are limited to the most specialized families, namely the Orchidaceae and Bromeliaceae (Gentry \& Dodson 1987), while the presence of species of Araceae, Gesneriaceae, Cactaceae, and pteridophytes would be expected in moister locations (Gentry \& Dodson 1987). In drier locations, epiphytes cope with stressful conditions of the canopy through different morphophysiological adaptations, and Crassulacean Acid Metabolism (CAM) is frequent in many epiphytic species (Lambers et al. 1998). This is probably the case with the epiphytic flora in the Jacarepiá dry forest, with an annual rainfall below 1000 mm (Sá 1992). Comparatively, rainfall in 
Jacarepiá is more similar to the dry forests from Ecuador $\left(800 \mathrm{~mm} \mathrm{y}^{-1}\right)$ than to other Atlantic forests located in Panama or Brazil (Fischer \& Araújo 1995, Zotz et al. 1999, Zotz \& Vollrath 2003, Borgo \& Silva 2003, Gonçalves \& Waechter 2003), with annual precipitations above $1,600 \mathrm{~mm}$.

In the Jacarepiá dry forest, two main groups of epiphytes are physiognomically evident in the forest established on a predominantly sandy soil with low water retention capacity (Sá 1992). The first group consists of bromeliads without connection to the soil, and the second group is composed by hemiepiphytes (species of Araceae and Orchidaceae) with soil connection during their entire life cycle or part of it.

A progressively higher proportion of the number of CAM species comparing to $\mathrm{C}_{3}$ has been reported from rainy to dry forests (Mooney et al. 1989, Zotz 2004). However, the contribution of CAM to total biomass or the number of individuals with CAM pathway in relation to that of $\mathrm{C}_{3}$ is still poorly investigated. For instance, results from a humid forest $\left(3,500 \mathrm{~mm} \mathrm{y}^{-1}\right)$ in Panama indicated that $19.4 \%$ out of the total number of species were CAM, but these represented less than $5 \%$ of the individuals in this wet forest (Zotz 2004). Although a general trend can be depicted, the participation in abundance of bromeliads which are frequently present in many wet or dry forest formations of the Neotropics is unclear. As dry forests are per se stressful habitats, a prevalence of CAM is expected in most bromeliad species in Jacarepiá, regardless of their abundance in the area.

Besides the analysis between CAM bromeliad species and CAM bromeliad abundance, the general abundance of epiphytes can be also investigated based on a phorophyte perspective due to different sizes and microhabitats available in their supportive trees (Johansson 1974). In this regard, although it is biologically reasonable to assume that large trees have higher abundance and richness of epiphytes, correlations between diameter and abundance are by no means the rule (see Ingram \& Nadkarni 1993, Moran et al. 2003). Some authors have suggested that correlations may occur because of longer exposition of the trunks to epiphytic seeds (Bennet 1987), while other authors have stated that the lack of correlation may occur due to environmental conditions, such as microclimatic variations, or accidents caused by foraging arboreal animals (Perry 1978, Zotz \& Vollrath 2003). Besides the influence of tree diameter, the microsites available on large trees are important for the vertical zonation of epiphytes, especially in humid forests (Johansson 1974) where epiphytes are more abundant and rich on the primary ramifications of phorophytes.
The study of epiphytes in dry forests could indicate strategies that enable them to colonize different microsites of phorophytes in spite of adverse environmental conditions. This work investigated the phanerogamic, herbaceous epiphytes of the dry forest at the Jacarepiá Ecological Reserve, with emphasis on two aspects. In the first, we investigated whether increase in tree diameter is followed by modifications in the abundance of general epiphytes: i) is tree diameter correlated with abundance of general epiphytes?; ii) is tree diameter correlated with abundance of holoepiphytes and hemiepiphytes? The second aspect investigated the epiphytic bromeliad community which dominates the forest physiognomy, to investigate how these plants occupy their supportive trees: iii) is tree diameter correlated with bromeliad abundance and richness? iv) are there differences in size between bromeliad supportive trees and trees devoided of these plants?; v) are there differences in the vertical occupation of bromeliads?; vi) are there differences in bromeliad microsite occupation?; and, vii) how is CAM spatially distributed among bromeliad species?

\section{Material and methods}

Study area - The dry forest of Jacarepiá is inserted within the State Ecological Reserve of Jacarepiá (SERJ), located in the municipality of Saquarema $107 \mathrm{~km}$ north of the city of Rio de Janeiro (22 $47^{\prime}$ ' $-22^{\circ} 57^{\prime} \mathrm{S}$ and $\left.42^{\circ} 20^{\prime}-42^{\circ} 43^{\prime} \mathrm{W}\right)$. The total area of the SERJ is $12.5 \mathrm{~km}^{2}$, regional rainfall is $987 \mathrm{~mm}_{\text {year }}{ }^{-1}$ (Sá 2002), and the predominant vegetation is a mosaic of plant communities called restinga, where six communities were described (Sá 1992): halophilous, psammophilous, reptant, scrub of Palmae, herbaceous swamp, and dry forest.

The dry forest is established on the sandy coastal plain, at an intermediate location between the Jacarepiá lagoon and the herbaceous swamp, parallel to the ocean (Cirne et al. 2003, Gebler et al. 2005). The soil is sandy, covered with a thin layer of debris with low water retention after rain. The canopy presents trees that can reach $20 \mathrm{~m}$ in height: Algernonia obovata (Müll. Arg.) Müll. Arg., Pterocarpus rohrii Vahl, Pseudopiptadenia contorta (DC.) G. P. Lewis \& M. P. Lima, Guapira opposita (Vell.) Reitz, and Alseis involuta K. Schum. are the most frequent tree species (Sá 1992).

Sampling - The list of epiphytic species occurring in the SERJ was based on random field sampling during five years, and on herbarium specimens deposited at Herbário do Jardim Botânico do Rio de Janeiro (RB). Species were either categorized as "holoepiphytes" (with no root emission to the soil) or "hemiepiphytes" (with connection to the ground at some period of their life cycle). Botanical vouchers were deposited at the Herbário do Jardim Botânico do Rio de Janeiro (RB). 
Data on epiphytes, phorophytes, and trees were based on the point-center quarter method (Cottam \& Curtis 1956) in the only remnant forest fragment of the region. Inside the forest, four groups of five $100 \mathrm{~m}$ long transects were established to sample 800 trees with a diameter at breast height (DBH) $\geq 5 \mathrm{~cm}$. The four groups of transects were 100-200 m away from one another.

The diameters, total heights, and species names of all 800 trees were recorded. The following data on the epiphytes were also recorded: i) epiphytic species; ii) life form (holo or hemiepiphyte), iii) height at which each epiphyte occurred on the phorophyte; iv) abundance; v) microsite of occurrence on the phorophyte (trunk; primary, secondary, tertiary ramification).

Because many epiphytic species may form clusters (genets) of ramets on tree trunks or branches, we used these clusters as measure of abundance, regardless the numbers of constituent ramets (e.g. one or many orchid bulbs or one or many bromeliad rosettes). Although one genet may break apart and constitute different clusters (Rauh 1990), the only pre-requisite to register one or two clusters was the physical distance between them. If one cluster of one epiphytic species was spatially distant from another cluster of the same species in the same tree branch or trunk, these clusters were recorded as "abundance equals two".

For some bromeliad species the photosynthetic pathway has already been published. For the other epiphytic bromeliads from Jacarepiá, the stable carbon isotope ratio $\left(\delta^{13} \mathrm{C}\right)$ was determined by isotope ratio mass spectrometry (Europa Automated Nitrogen Carbon Analysis - ANCA SL System, Europa Ltd, Crewe, UK) as described in Reinert et al. (1997). In this paper we follow other studies (e.g. Medina et al. 1977) and consider $\delta^{13} \mathrm{C}$ values higher (i.e. less negative) than $-20 \%$ as an indication of CAM.

Data analysis - Spearman's rank correlation (Zar 1999) was used to test whether or not larger diameters harbored more epiphytes, holoepiphytes, hemiepiphytes, and bromeliads. The same test was used to verify possible correlations between phorophyte diameter and bromeliad richness.

Because diameter distribution of trees have no normal distribution even after log transformation, we used box plots with median and confidence intervals (McGill et al. 1978) to verify differences i) in the diameter of trees with and without epiphytes; ii) in the diameter of trees with and without bromeliads; iii) in the height and diameter of phorophytes of bromeliad species; iv) in the height at which bromeliad species become established on the phorophyte.

The confidence intervals (represented by notches) were calculated based on the range of interquartiles of data and the number of observations for each group. The standard deviation of the median was calculated based on the Gaussian-based asymptotic approximation, which is reasonably applicable to other data distribution (McGill et al. 1978).

The chi-square test (Zar 1999) was used to verify the differences in bromeliad proportions on the tree trunk, primary, secondary, and tertiary ramifications of the tree crown. To assure robustness in this statistical test (Zar 1999), we used species with abundance $\geq$ seven clusters.

\section{Results}

Thirty-nine species from six families of epiphytes were collected in the SERJ area (table 1), comprising four hemiepiphytes $(10.3 \%)$ and 35 holoepiphytes (89.7\%). Orchids, bromeliads, and other epiphytes with no soil connection were represented by approximately one-third of the species each $(30.7 \%, 30.7 \%$, and $28.2 \%$ respectively).

In the sampled trees, 119 trees (14.9\%) from 24 families and 49 species hosted epiphytic plants. Phorophytes were present in almost all diameters and tree heights, but the diameter of phorophytes was larger than that of trees with no epiphytes (figure 1). Phorophytes hosted a few or several clusters of epiphytes (figure 2) but there was no correlation between epiphyte abundance and phorophyte diameter ( $\mathrm{rs}=0.12, P=0.17, N=119$ ). Most phorophytes $(91.6 \%)$ harbored holoepiphytes and a smaller number $(10.9 \%)$ harbored hemiepiphytes. Holoepiphytes occurred in trees of all diameters in the area $(5.1$ to $61.0 \mathrm{~cm})$, whereas hemiepiphytes occurred on thinner trees $(5.7$ to $32.2 \mathrm{~cm}$ ). No correlation was found between the abundance of either life forms and the phorophyte height $\left(\mathrm{rs}_{\mathrm{hemi}}=0.31, P=0.28, N=13\right.$;

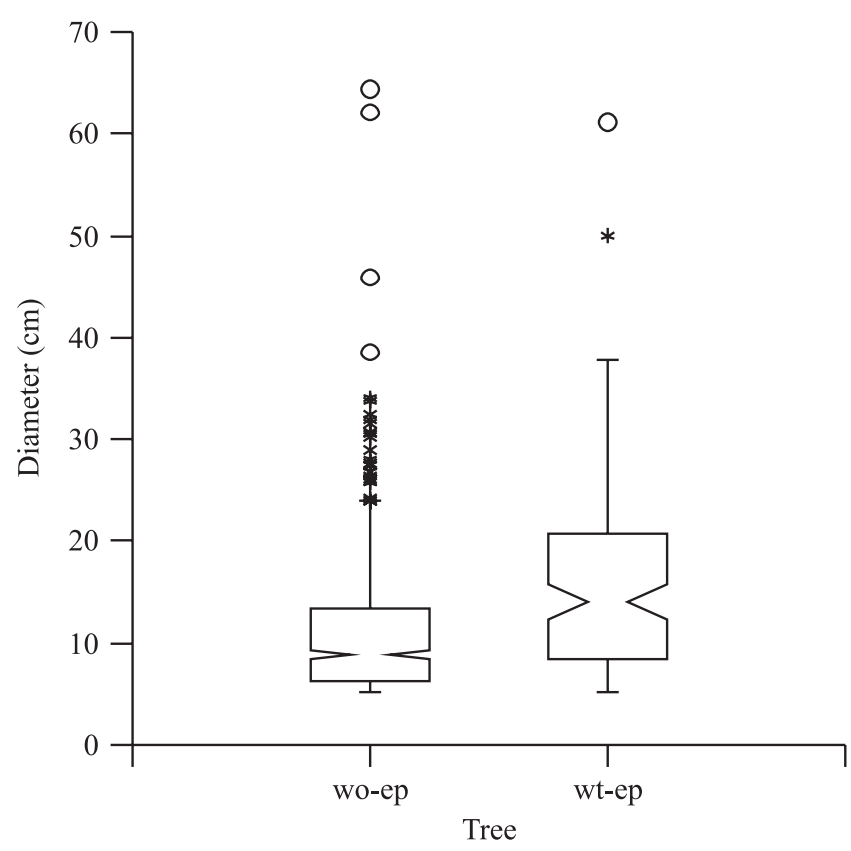

Figure 1. Tree diameter of trees with epiphytes (wt-ep) and without epiphytes (wo-ep) in the dry forest of Jacarepiá, Brazil. (* = values larger than 1.5 times the range of interquartiles; $\mathrm{O}=$ values lager than 3 times the range of interquartiles). 
Table 1. General epiphytes in the region of the Ecological Reserve of Jacarepiá, Brazil. (Holo $=$ holoepiphytes; hemi $=$ hemiepiphytes).

\begin{tabular}{|c|c|c|c|}
\hline Families & Species & Voucher collections & Life form \\
\hline \multirow[t]{4}{*}{ ARACEAE } & 1. Anthurium coriaceum G. Don & T. Fontoura 204 & Holo \\
\hline & 2. Anthurium harrisii (Graham) G. Don & T. Fontoura 205 & Hemi \\
\hline & 3. Anthurium pentaphyllum (Aubl.) G. Don & T. Fontoura 337 & Hemi \\
\hline & 4. Philodendron pedatum (Hook.) Kunth & T. Fontoura 301 & Hemi \\
\hline \multirow[t]{12}{*}{ BROMELIACEAE } & 5. Aechmea fasciata (Lindl.) Baker & T. Fontoura 138, 194 & Holo \\
\hline & 6. Aechmea floribunda Mart. ex Schult. f. & T. Fontoura 212 & Holo \\
\hline & 7. Aechmea nudicaulis (L.) Griseb. & G. Martinelli 4540 & Holo \\
\hline & 8. Aechmea sphaerocephala Baker & T. Fontoura 193, 214 & Holo \\
\hline & 9. Billbergia amoena (Lodd.) Lindl. & T. Fontoura 74,137 & Holo \\
\hline & 10. Billbergia pyramidalis (Sims) Lindl. & T. Fontoura 175 & Holo \\
\hline & 11. Neoregelia eltoniana W. Weber & T. Fontoura 207 & Holo \\
\hline & 12. Tillandsia gardneri Lindl. & G. Martinelli 4535 & Holo \\
\hline & 13. Tillandsia stricta Sol. ex Sims & J. Fontella 3013, 3015 & Holo \\
\hline & 14. Tillandsia usneoides (L.) L. & V.S. Fonseca 296 & Holo \\
\hline & 15. Vriesea procera (Mart. ex Schult.f.) Wittm. & T. Fontoura 75,335 & Holo \\
\hline & 16. Vriesea sucrei L. B. Sm. \& Read & T. Fontoura $139 \mathrm{~A}$ & Holo \\
\hline \multirow[t]{8}{*}{ CACTACEAE } & 17. Epiphyllum phyllanthus (L.) Haw. var. phyllanthus & H. C. Lima 4728 & Holo \\
\hline & 18. Hylocereus undatus (Haw.) Britton \& Rose & M. F. Freitas 200 & Holo \\
\hline & 19. Lepismium cruciforme (Vell.) Miq. & T. Fontoura 305 & Holo \\
\hline & 20. Rhipsalis baccifera (J. S. Muell.) Stearn & G. Martinelli 7365 & Holo \\
\hline & 21. Rhipsalis crispata (Haw.) Pfeiff. & T. Fontoura 307 & Holo \\
\hline & 22. Rhipsalis oblonga Loefgr. & M. F. Freitas 206, 229 & Holo \\
\hline & 23. Rhipsalis pachyptera Pfeiff. & M. F. Freitas 117, 212 & Holo \\
\hline & 24. Selenicereus setaceus (Salm-Dyck) A. Berger ex Werderm. & M. F. Freitas 181, 224 & Holo \\
\hline GESNERIACEAE & 25. Codonanthe gracilis (Mart.) Hanst. & T. Fontoura 200 & Holo \\
\hline \multirow[t]{13}{*}{ ORCHIDACEAE } & 26. Brassavola cf. flagelaris Barb. Rodr. & C. Farney 2226 & Holo \\
\hline & 27. Campylocentron robustum Cogn. & T. Fontoura 206 & Holo \\
\hline & 28. Cattleya guttata Lindl. & P. Ochioni $s / n$ & Holo \\
\hline & 29. Cyrtopodium sp. & J. Fontella 3166 & Holo \\
\hline & 30. Notylia sp. & C. Farney 2669 & Holo \\
\hline & 31. Oeceoclades maculata (Lindl.) Lindl. & T. Fontoura 312 & Holo \\
\hline & 32. Oncidium ciliatum Lindl. & T. Fontoura $312 B$ & Holo \\
\hline & 33. Oncidium lemminghei E. Morren ex Lindl. & V. F. Ferreira 392 & Holo \\
\hline & 34. Pleurothalis saundersiana Reich.f. & T. Fontoura 210 & Holo \\
\hline & 35. Pleurothalis sp. & T. Fontoura $312 \mathrm{~A}$ & Holo \\
\hline & 36. Polystachia sp. & T. Fontoura 196, 198 & Holo \\
\hline & 37. Trichocentrum fuscum Lindl. & T. Fontoura $312 C$ & Holo \\
\hline & 38. Vanilla $\mathrm{sp}$. & T. Fontoura s/n & Hemi \\
\hline PIPERACEAE & 39. Peperomia corcovadensis Gardner & T. Fontoura 195, 201 & Holo \\
\hline
\end{tabular}




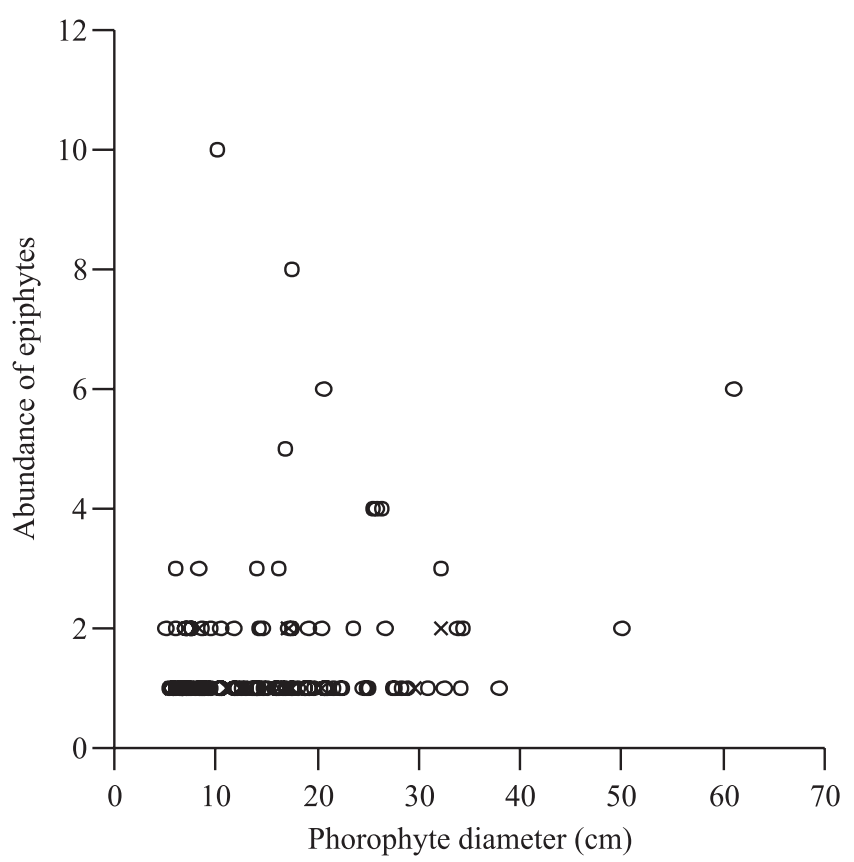

Figure 2. Abundance distribution of epiphytes on phorophyte diameters in the dry forest of Jacarepiá, Brazil. ( $O=$ holoepiphytes; $X=$ hemiepiphytes).

$\left.\mathrm{rs}_{\text {holo }}=0.01, P=0.86, N=109\right)$ or the abundance of either life form and the phorophyte diameter $\left(\mathrm{rs}_{\mathrm{hemi}}=0.17\right.$, $\left.P=0.55, N=13 ; \mathrm{rs}_{\text {holo }}=0.13, P=0.17, N=109\right)$.

Eighty two phorophytes (68.9\%) harbored at least one of the nine bromeliad species (table 2). Billbergia amoena e Tillandsia usneoides were represented by only one cluster on the sampled trees. The median diameter of these phorophytes ranged from 9.5 to $61.0 \mathrm{~cm}$ and median height was between 7.0 and $16.0 \mathrm{~m}$ (table 2). Bromeliad phorophytes had larger diameters than trees without bromeliads (figure 3). Bromeliad abundance was correlated with tree diameter ( $\mathrm{rs}=0.2, P=0.05, N=79$ ), but no correlation was verified between the number of bromeliad species and phorophyte diameter ( $\mathrm{rs}=0.16$, $P=0.17, N=79)$.

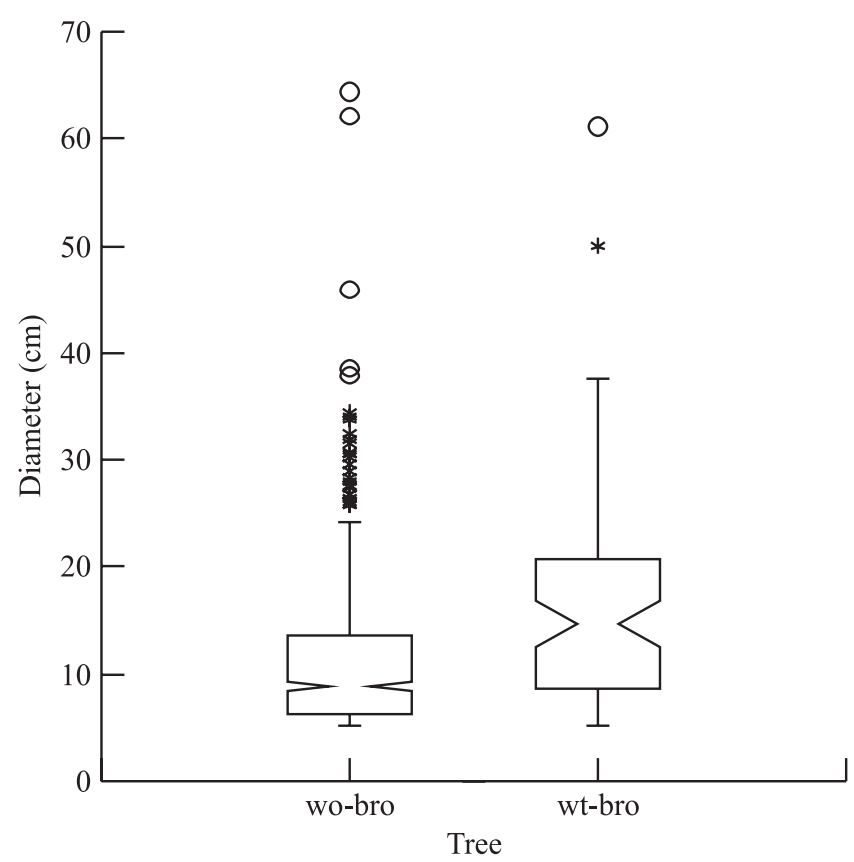

Figure 3. Tree diameter of trees with bromeliads (wt-bro) and without bromeliads (wo-bro) in the dry forest of Jacarepiá, Brazil. (*= values larger than 1.5 times the range of interquartiles; $\mathrm{O}=$ values larger than three times the range of interquartiles).

Table 2. Bromeliad species, abundance of groups $(\mathrm{N})$ and natural abundance of stable carbon isotope ratio $\left({ }^{13} \mathrm{C} \% \mathrm{o}\right)$ of the epiphytic species of Jacarepiá. Phorophyte minimum - maximum (median) diameter and, minimum - maximum (median) height in the dry forest of Jacarepiá, Brazil.

\begin{tabular}{|c|c|c|c|c|c|c|c|c|}
\hline Species & $\mathrm{N}$ & & iameter & $\mathrm{cm})$ & & Height ( & & $\delta^{13} \mathrm{C}(\%)$ \\
\hline Aechmea fasciata & 50 & 5.1 & - & 61.00 & 3.0 & - & $16(9.5)$ & -14.04 \\
\hline Aechmea floribunda & 7 & 7.0 & - & $25.8(17.5)$ & 5.0 & - & $14(7.0)$ & -14.41 \\
\hline Aechmea sphaerocephala & 3 & 8.6 & - & $26.7(15.9)$ & 4.0 & - & $13(9.0)$ & -14.01 \\
\hline 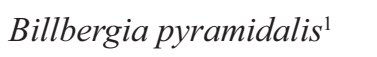 & 4 & 10.2 & - & $32.2(28.3)$ & 7.0 & - & $14(10.5)$ & -15.60 \\
\hline Billbergia amoena ${ }^{2}$ & 1 & 61.0 & $(61.0)$ & & 16.0 & $(16.0)$ & & -16.01 \\
\hline Neoregelia eltoniana & 11 & 6.7 & - & $27.7(9.5)$ & 4.0 & - & $14(7.0)$ & -14.64 \\
\hline Tillandsia stricta ${ }^{2}$ & 2 & 34.1 & - & $61(47.5)$ & 16.0 & - & $(16.0)$ & -12.98 to -13.71 \\
\hline Tillandia usneoides ${ }^{2}$ & 1 & 10.5 & $(10.5)$ & & 10.0 & $(10.0)$ & & -15.10 \\
\hline Vriesea procera ${ }^{2}$ & 34 & 5.7 & - & $33.8(14.3)$ & 5.0 & - & $14(8.5)$ & -24.62 \\
\hline TOTAL & 113 & & & & & & & \\
\hline
\end{tabular}

${ }^{1}$ Medina et al. 1977, ${ }^{2}$ Reinert et al. 1997. 
The diameter of phorophytes with Neoregelia eltoniana was smaller than the diameter of phorophytes harboring the majority of other bromeliad species (Aechmea fasciata, B. amoena, B. pyramidalis, T. stricta, $V$. procera; figure 4A). Phorophytes with $A$. fasciata, $B$. amoena, $T$. stricta and T. usneoides were taller than those with $N$. eltoniana, but there was no difference between the heights of phorophytes with other bromeliad species (figure 4B).
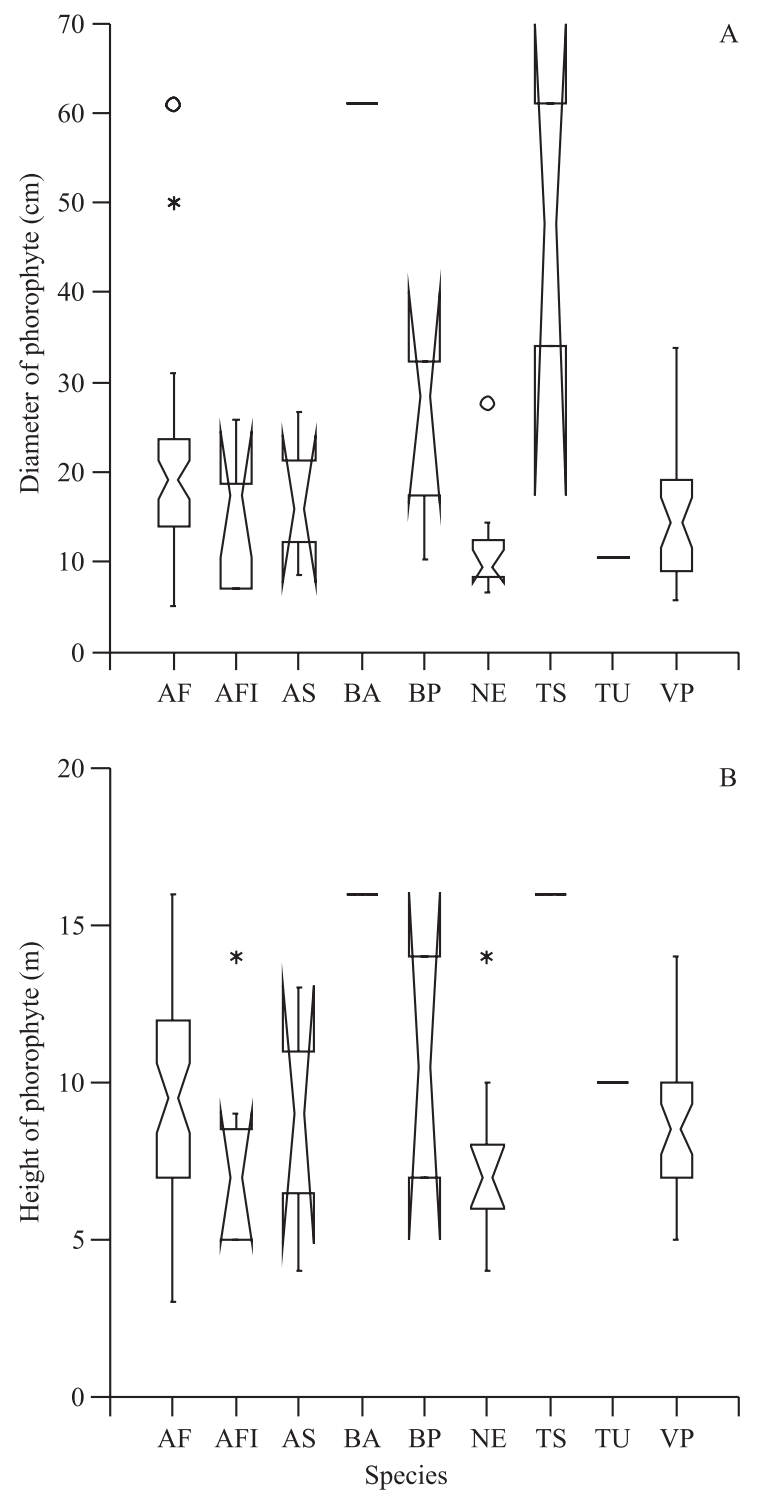

Figure 4. Phorophyte diameters (A) and phorophyte heights (B) of bromeliad species in the dry forest of Jacarepiá, Brazil. $(\mathrm{AF}=$ Aechmea fasciata $; \mathrm{AFl}=A$. floribunda $; \mathrm{AS}=A$. sphaerocephala; $\mathrm{BP}=$ Billbergia pyramidalis; $\mathrm{BA}=B$. amoena $; \mathrm{NE}=$ Neoregelia eltoniana $; \mathrm{TS}=$ Tillandsia stricta $;$ $\mathrm{TU}=$ T. usneoides $; \mathrm{VP}=$ Vriesea procera $).(*=$ values larger than 1.5 times the range of interquartiles; $O=$ values larger than three times the range of interquartiles).
Of the nine epiphytic bromeliad species, eight were CAM $\left({ }^{13} \mathrm{C}\right.$ values higher than $-20 \%$ ) with $\mathrm{C}_{3}$ being represented by $V$. procera (table 2 ).

Billbergia pyramidalis becomes established at the lower parts of trees while Tillandsia stricta becomes established at the higher parts (figure 5). There were no vertical establishment differences in most bromeliad species. Almost half of the bromeliads (43.4\%) occurred on the trunks, whereas $29.2 \%$ occurred on the primary ramification of the phorophytes. Three out of four species analyzed occupied trunks more than expected, and only $V$. procera occurred on the primary, secondary, and tertiary ramifications more than expected.

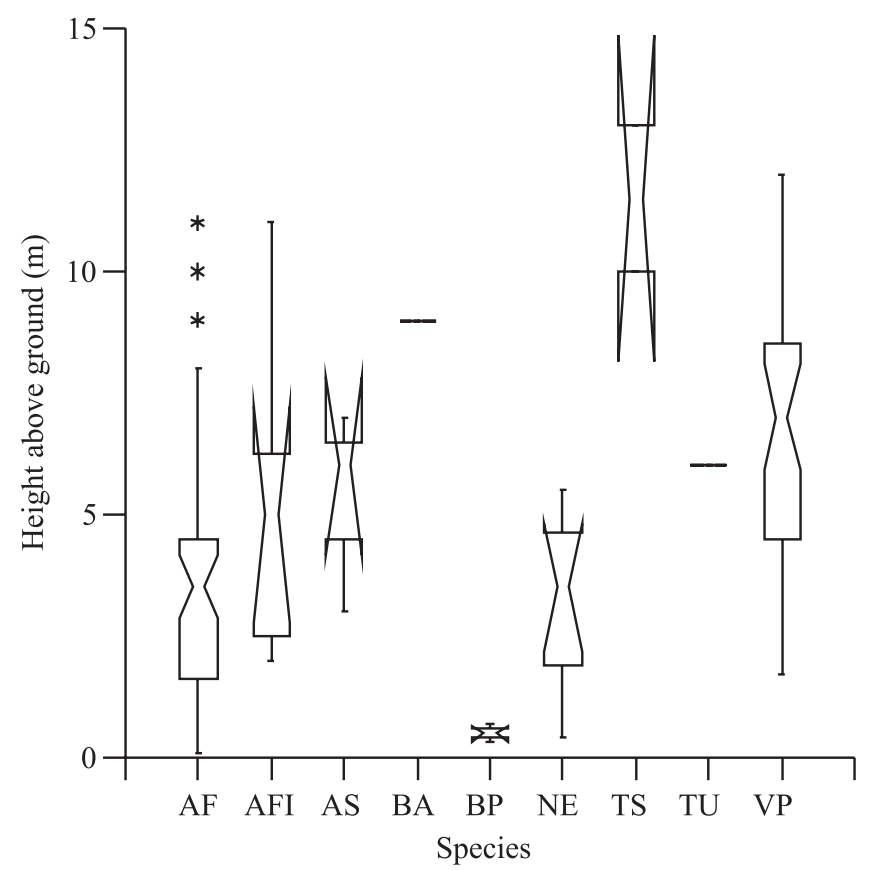

Figure 5. Vertical distribution of bromeliad species above ground. See table 2 for acronyms. $(\mathrm{AF}=$ Aechmea fasciata; $\mathrm{AFl}=$ A. floribunda $; \mathrm{AS}=$ A. sphaerocephala $; \mathrm{BP}=$ Billbergia pyramidalis; $\mathrm{BA}=B$. amoena $; \mathrm{NE}=$ Neoregelia eltoniana $;$ $\mathrm{TS}=$ Tillandsia stricta $; \mathrm{TU}=T$. usneoides $; \mathrm{VP}=$ Vriesea procera $).(*$ values larger than 1.5 times the range of interquartiles).

\section{Discussion}

A greater proportion of orchid and bromeliad among the species present in the epiphytic habitat is an expected result in drier habitats (Gentry \& Dodson 1987), but the low humidity present in this dry forest is sufficient to allow the occurrence of different species of Gesneriaceae, Araceae, and Cactaceae, which are 
unexpected in dry areas. In addition to the presence of species of different epiphyte families, the predominance of species without connection to the soil indicates that although this dry forest is located close to the sea, thus being subjected to marine aerosols, these plants have mechanisms that help them avoid or cope with such particles, which could affect their water absorption, as occurs with plants that are not tolerant to salts (Lambers et al. 1998). Since the various morphophysiological mechanisms of epiphytic plants (e.g. crassulacean acid metabolism, roots with velamen) prevent excessive water loss (Benzing 1995, 2000), but not the entry of salt particles, the external canopy would act as an important physical barrier retaining $\mathrm{NaCl}$ on tree branches and leaves before reaching bromeliad rosettes and other epiphytes on the tree trunks. Because of low pluviosity in the region, it seems improbable that the canopy of this dry forest has the same function as already reported to humid areas (Nadkarni 1986, Benzing 1990) where chemical modifications occur continuously because of elevated precipitation.

Phorophytes of general epiphytes have larger sizes than trees that do not host these plants, a pattern already reported for forested areas in Bahia (Alves 1990, Alves 2005), Ecuador (Dunn 2000), and Central America (Zotz $\&$ Vollrath 2003). One of the factors that may contribute toward this pattern is that large trees have been there longer, as usually the largest trees are also the oldest, being easier targets to be reached by seeds (Bennett 1987). Furthermore, smaller trees do not present sufficiently developed microsites (e.g. primary ramifications, adequate perching sites to allow dispersal by birds) to harbor epiphytes, dispersed either by the wind (orchids, Tillandsia spp., and Vriesea spp.), small mammals (for species of Araceae), or ants (Rhipsalis spp.).

The occurrence of hemiepiphytes was restricted to trees with diameters up $32.2 \mathrm{~cm}$. The predominance of holoepiphytes on $91.6 \%$ of the sampled trees (and in the region as a whole) indicates that this life form has been more successful in the conquest of this particular region, when compared to hemiepiphytes that depend on their roots to absorb water and nutrients from the soil. Although holoepiphytes are subjected to a discontinuous supply of water and nutrients due to its lack of roots (Benzing 1990), its various morphophysiological adaptations (e.g. leaf indumentum, leaf withering, bulbs) are apparently sufficient to allow its greater abundance and number of species in the dry forest. Comparatively, the Jacarepiá forest is drier for hemiepiphytes, since the sandy soil hardly retains water, than for holoepiphytes that do not have any connection to the soil but are capable of absorbing water and nutrients from the air and throughfall using various adaptations.

In general, the occurrence of phorophytes with larger diameters does not mean a greater abundance of epiphytes, as shown by the lack of correlation between abundance and diameter. Two sources of variation may have contributed toward this result. The first is represented by different epiphytic species and life histories, while the second may be represented by safe sites scattered in various ways among the tree species which, together, could affect epiphytic establishment and germination, resulting in the abundance variation observed in this forest. In the case of dry forests, the establishment of additional epiphytic seeds would be mainly dependent on tree trunk characteristics as suggested by Callaway et al. (2002), rather than on the presence of avascular plants present on the tree branches of humid forests, which would facilitate the presence of vascular epiphytes (Johansson 1974).

Based on the variability of epiphyte abundance, we are tempted to suggest an aggregated pattern of epiphytic distribution among trees, as is the case with some species of bromeliads in Brazil (Cogliatti-Carvalho \& Rocha 2001) and general epiphytes in Venezuela (Nieder et al. 2000). Nevertheless, specific analyses would be required to test whether epiphytes differ from random or aggregated patterns in their horizontal distribution.

The correlation between tree diameter and bromeliad abundance and the lack of correlation between diameter and number of bromeliad species show that the largest tree diameters host more bromeliads of the same species but not more species of this plant family. Since the specificity between epiphytic and tree species is an exception (Benzing 1990), we may exclude the possibility that unique and exclusive biotic or abiotic conditions explain that more seeds of a particular bromeliad germinate on the trunk of a tree species to the detriment of other species. Some studies have demonstrated that, for some bromeliad species with terrestrial and epiphytic habit, a continuous humidity supply is one of the most important conditions for seed germination. Such results were obtained with Aechmea nudicaulis and A. floribunda, which occur on the soil of drier regions of shrub restinga (Pinheiro \& Borghetti 2003), where their seeds need at least four days in an embedded state to germinate. For strictly epiphytic plants, Callaway et al. (2002) demonstrated that, in subtropical forests of the United States, the main factor that increases the abundance of Tillandsia usneoides on some tree trunks is their capacity to retain water. This is probably also the case with the tree trunks of the dry forest of Jacarepiá. Bromeliad 
seeds would germinate on the trunks of phorophytes with the best water retention capacity, which would ensure a continuous water supply. The limitation in number of species would be due to the verticality of the trunks, which prevents the germination and development of a great number of bromeliad species.

On the larger trees of the forest, the same diameter or height range, say $5 \mathrm{~m}$ tall trees or trees $7 \mathrm{~cm}$ in diameter, can supply a substrate for different bromeliad species. On the other hand, although this substrate is potentially available to all bromeliad species, some species (for example, $N$. eltoniana) only use a small range of diameters. Thus, the comparison between diameter and height of trees hosting $N$. eltoniana with those of trees hosting $A$. fasciata indicates that $N$. eltoniana occurs in thinner and lower trees than A. fasciata. The fact that $N$. eltoniana was not observed on larger diameters does not mean that its seeds are not reaching them; consequently, further investigations should be conducted to check the role seed-dispersing animals play in the horizontal (tree diameter) and vertical (tree height) distribution patterns reported here. Although the classic factors limiting the occurrence of bromeliads are light and humidity (Benzing 1990, 2000, Reinert 1998), some studies have pointed out that ants or frugivorous animals can play an important role in observed epiphytic plant patterns (Nieder et al. 2000, Alves 2005). These animals can take bromeliads to specific places in the forest or to certain tree diameters due to their feeding habits. Epiphyte bromeliads occupy almost the entire canopy of the dry forest, where only two species typical of understorey (B. pyramidalis) and of canopy (T. stricta) could be identified, while intermediate heights are occupied by different species that succeed one another throughout the canopy.

The results of epiphytic microsite occupation suggest that the expected pattern of distinct vertical occupation zones on large trees suggested by Johansson (1974) does not match the trees in the studied area because only two species were found to be characteristic of distinct zones ( $T$. stricta in the upper and B. pyramidalis in the lower part of the canopy) and most bromeliad species are restricted to tree trunks. Although large trees usually provide appropriate microsites allowing higher abundance and species richness in the upper part of the trunk and on the main ramification of the tree crown, as already recorded in humid areas (see ter Steege \& Cornelissen 1989, Van Leerdam et al. 1990, Ingram \& Nadkarni 1993), the tree crowns from the Jacarepiá dry forest seem to be an overexposed site for bromeliad establishment. In contrast, the subcanopy and understorey regions would maintain enough humidity to enable bromeliads and general epiphytes to complete their life cycles. Since low rainfall is but one aspect to elucidate epiphytic occupation on trees, further studies should address levels of mist and dew formation which are also important factors contributing to the epiphytic presence in forested areas.

Vriesea procera was significantly more exposed than A. fasciata, as it was higher and occurred more often on ramifications than on the main trunk. If CAM abundance is related to water economy, the fact that a single $\mathrm{C}_{3}$ species was subjected to more exposed conditions is remarkable. Our data contrast with those presented by Zotz (2004), who investigated the epiphytes in a wet forest of Panama and found a higher prevalence of CAM at greater heights and more exposed tree branches.

Additionally, the importance of CAM is challenged among epiphytic bromeliads if we consider species abundance instead of species number: the importance of CAM changes from $90 \%$ (eight in nine species) to $70 \%$ ( 79 specimens) of bromeliads. Even though CAM abundance represents a lower percentage when compared with CAM species, the results presented here in cannot be classified as "low". These results emphasize the continuing need to broaden our knowledge of bromeliad physiology and to better understand their ability to inhabit dry forests.

Acknowledgments - Funds for this study were provided by Coordenação de Aperfeiçoamento de Pessoal de Nível Superior (Capes) and field support was provided by Projeto Restinga (Instituto Jardim Botânico do Rio de Janeiro). The author is grateful for field assistance by Jorge Caruso, Cecília Amorim, Fernando Tatagiba, Gina Cardinott and Eduardo Amado. Special thanks go to Cyl Farney Catarino de Sá, Dorothy Sue Dunn de Araújo and Fábio Scarano who provided invaluable help to start and complete this work. The laboratory of Professor Howard Griffiths at Newcastle University provided infrastructure for the physiological analysis.

\section{References}

ALVES, M.C. 1990. The role of cacao plantations in the conservation of the Atlantic forest of southeastern Bahia, Brazil. Ph.D. dissertation, University of Florida, Florida.

ALVES, T.F. 2005. Distribuição geográfica, forófitos e espécies de bromélias epífitas nas matas e plantações de cacau da região de Una, Bahia. Tese de doutorado, Universidade Estadual de Campinas, Campinas.

BENNETT, B. 1987. Spatial distribution of Catopsis and Guzmania (Bromeliaceae) in southern Florida. Bulletin of the Torrey Botanical Club 114:265-271. 
BENZING, D.H. 1990. Vascular epiphytes. General biology and related biota. Cambridge University Press, Cambridge.

BENZING, D.H. 1995. Vascular epiphytes. In Forest canopies (M.D. Lowman \& N.M. Nadkarni, eds.). Academic Press, California, p.225-254.

BENZING, D.H. 2000. Bromeliaceae. Profile of an adaptive radiation. Cambridge University Press, Cambridge.

BORGO, M. \& SILVA, S.M. 2003. Epífitos vasculares em fragmentos de floresta ombrófila mista, Curitiba, Paraná, Brasil. Revista Brasileira de Botânica 26:391-401.

CALLAWAY, R.M., REINHART, K.O., MOORE, G.W. 2002. Epiphyte host preferences and host traits: mechanisms for species-specific interactions. Oecologia 132:221230.

CIRNE, P., ZALUAR, H.L.T. \& SCARANO, F.R. 2003. Plant diversity, interspecific associations, and postfire resprouting on a sandy spit in a Brazilian coastal plain. Ecotropica 9:33-38.

COGLIATTI-CARVALHO, L. \& ROCHA, C.F.D. 2001. Spatial distribution and preferential substrate of Neoregelia johanis (Carriére) L.B. Smith (Bromeliaceae) in a disturbed area of Atlantic Rainforest at Ilha Grande, RJ, Brazil. Revista Brasileira de Botânica 24:389-394.

COTTAM, G. \& CURTIS, J.T. 1956. The use of distance measures in phytosociological sampling. Ecology 37 : 451-460.

DUNN, R.R. 2000. Bromeliad communities is isolated trees and three successional stages of an Andean cloud forest in Ecuador. Selbyana 21:137-143.

FISCHER, E. \& ARAÚJO, A.C. 1995. Spatial organization of a bromeliad community in the Atlantic rainforest, southeastern Brazil. Journal of Tropical Ecology 11: 559-567.

GENTRY, A. \& DODSON, C.H. 1987. Diversity and biogeography of Neotropical vascular epiphytes. Annals of the Missouri Botanical Gardens 74:205-233.

GEBLER, A., DUARTE, H.M., FRANCO, A.C., LÜTTGE, U., MATTOS, E.A., NAHM, M., SCARANO, F.R., ZALUAR, H.L.T. \& RENNENBERG, H. 2005. Ecophysiology of selected tree species in different plant communities at the periphery of the Atlantic Forest of SE-Brazil II. Spatial and ontogenetic dynamics in Andira legalis, a deciduous legume tree. Trees 19: 510-522.

GONÇALVES, C.N. \& WAECHTER, J.L. 2003. Aspectos florísticos e ecológicos de epífitos vasculares sobre figueiras isoladas no norte da planície costeira do Rio Grande do Sul. Acta Botanica Brasilica 17:89-100.

INGRAM, S. \& NADKARNI, N.M. 1993. Composition and distribution of epiphytic organic matter in a Neotropical cloud forest, Costa Rica. Biotropica 25:370-383.

JOHANSSON, D.R. 1974. Ecology of vascular epiphytes in West African rain forest. Acta Phytogeographica Suecica 59:1-136.
LAMBERS, H., CHAPIN III, F.S. \& PONS, T. 1998. Plant physiological ecology. Springer-Verlag, New York.

MCGILL, R., TUKEY, J.W. \& LARSEN, W.A. 1978. Variations in box-plots. American Statistician 32:12-16.

MOONEY, H.A., BULLOCK, S.H. \& EHLERINGER, J.R. 1989. Carbon isotope ratios of plants of a tropical forest in Mexico. Functional Ecology 3:137-142.

MORAN, R.C., KLIMAS, S. \& CARLSEN, M. 2003. Low-trunk ferns on tree ferns versus angiosperms in Costa Rica. Biotropica 35:48-56.

MEDINA, E., TROUGHTON, J.H. \& MEDINA, J.D. 1977. Physiological ecology of $\mathrm{CO}_{2}$ fixation in Bromeliaceae. Flora 166:137-152.

NADKARNI, N.M. 1986. The nutritional effects of epiphytes on host trees with special reference to alteration of precipitation chemistry. Selbyana 9:44-51.

NIEDER, J., ENGWALD, S., KLAWUN, M. \& BARTHLOTT, W. 2000. Spatial distribution of vascular epiphytes (including hemiepiphytes. in a lowland Amazonian rain forest (Surumoni Crane Plot) of southern Venezuela. Biotropica 32:385-396.

PERRY, D.R. 1978. A method of access into the crowns of emergent and canopy trees. Biotropica 10:155-157.

PINHEIRO, F. \& BORGHETTI, F. 2003. Light and temperature requirements for germination of seeds of Aechmea nudicaulis (L.) Grisebach and Streptocalyx floribundus (Martius ex Schultes f.) Mez (Bromeliaceae). Acta Botanica Brasilica 17:27-35.

RAUH, W. 1990. The bromeliad lexicon. Blandford, London.

REINERT, F. 1998. Epiphytes: photosynthesis, water balance and nutrients. Oecologia Brasiliensis 4:87-108.

REINERT, F., GRIFFITHS, H., WILSON, J., RIBAS, L., CARDINOT, G. \& ROBERTS, A. 1997. Gradation in nutrient composition and photosynthetic pathways across the restinga vegetation of Brazil. Botanica Acta 110:135-142.

SÁ, C.F.C. 1992. A vegetaçäo da restinga de Ipitangas, Reserva Ecológica Estadual de Jacarepiá, Saquarema (RJ) fisionomia e listagem das angiospermas. Arquivos do Jardim Botânico Rio de Janeiro 31:87-102.

SÁ, C.F.C. 2002. Regeneração de um trecho de floresta de restinga na Reserva Ecológica Estadual de Jacarepiá, Saquarema, Estado do Rio de Janeiro: II - Estrato arbustivo. Rodriguésia 53:5-23.

TER STEEGE, H. \& CORNELISSEN, J.H.C. 1989. Distribution and ecology of vascular epiphytes in lowland rain forest of Guyana. Biotropica 21:331-339.

VAN LEERDAM, A., ZAGT, R.J. \& VENEKLAS, E.J. 1990. The distribution of epiphyte growth-forms in the canopy of a Colombian cloud-forest. Vegetatio 87:59-71.

ZAR, J.H. 1999. Biostatistical analysis. Prentice Hall, New Jersey.

ZOTZ, G. 2004. How prevalent is crassulacean acid metabolism among vascular epiphytes? Oecologia 138:184-192. 
ZOTZ, G., BERMELJO, P. \& DIETZ, H. 1999. The epiphyte vegetation of Annona glabra on Barro Colorado Island, Panamá. Journal of Biogeography 26:761-776.
ZOTZ, G. \& VOLLRATH, B. 2003. The epiphyte vegetation of the palm Socratea exorrhiza - correlations with tree size, tree age and bryophyte cover. Journal of Tropical Ecology 19:81-90. 